\title{
Antinociceptive activity of sulfated carbohydrates from the red algae Bryothamnion seaforthii (Turner) Kütz. and B. triquetrum (S.G. Gmel.) M. Howe
}

G.S.B. Viana ${ }^{1}$, A.L.P. Freitas², M.M.L. Lima ${ }^{1}$, L.A.P. Vieira², M.C.H. Andrade ${ }^{2}$ and N.M.B. Benevides ${ }^{2}$

\author{
Departamentos de ${ }^{1}$ Fisiologia e Farmacologia, and \\ Bioquímica, Faculdade de Medicina, Universidade Federal do Ceará, \\ Fortaleza, CE, Brasil
}

\section{Correspondence}

G.S.B. Viana

Departamento de Fisiologia e

Farmacologia, UFC

Rua Barbosa de Freitas, 130/1100

60170-020 Fortaleza, CE

Brasil

Fax: +55-85-242-3064

E-mail: osorio@ roadnet.com.br

Research supported by CNPq.

Received May 29, 2001

Accepted March 21, 2002

\section{Abstract}

We report the antinociceptive activity, determined by the writhing, formalin and hot-plate tests in mice, of crude (F0/60), lectin and carbohydrate fractions isolated by ammonium sulfate precipitation $(0$ to $60 \%$ ) from Bryothamnion seaforthii and B. triquetrum, species of red algae. Not only fraction F0/60 but also lectins from both species significantly inhibited acetic acid-induced abdominal contractions after intraperitoneal or oral administrations. In the formalin test, lectins ( 1 and $5 \mathrm{mg} / \mathrm{kg}$, ip , and 5 to $20 \mathrm{mg} / \mathrm{kg}, p o$ ) inhibited the $1 \mathrm{st}$ and 2nd phases ( 5 and $20 \mathrm{~min}$, respectively), but the effect occurred predominantly on the 2 nd phase. The effects of the lectins were totally or partially reversed by naloxone $(2 \mathrm{mg} / \mathrm{kg}, s c)$ in the $1 \mathrm{st}$ and $2 \mathrm{nd}$ phases, respectively. Experiments performed with lectins in the absence and presence of avidin $(1 \mathrm{mg} / \mathrm{kg}, i p)$ and D-mannose $(1 \mathrm{mg} / \mathrm{kg}$, ip) showed that avidin did not interfere with the effect of $B$. seaforthii lectin but partially reversed the effect of $B$. triquetrum lectin. DMannose completely reversed the effects of both species. F0/60 fractions from both algae significantly increased the latency time in response to thermal stimuli, and naloxone reversed antinociception, indicating the involvement of the opioid system in both the peripheral and central effects of the fractions. In the writhing test, the carbohydrate fractions were the most active, inhibiting the contractions by 71 and $79 \%$ (B. triquetrum) and by 46 and $69 \%$ (B. seaforthii) at doses of 1 and $5 \mathrm{mg} / \mathrm{kg}$, ip, respectively. Sulfated carbohydrate fractions of $B$. seaforthii and $B$. triquetrum, containing only about $5 \%$ protein as contaminants, are probably responsible for the antinociceptive effects of these red algae.

\section{Key words}

- Red algae

- Bryothamnion seaforthii

- Bryothamnion triquetrum

- Carbohydrates

- Antinociceptive effect 


\section{Introduction}

Lectins are ubiquitous glycoproteins with specific and reversible carbohydrate-binding activity widely found in nature, including plant and algal tissues $(1,2)$. Although the functions of these proteins in plants are just beginning to be understood, lectins are becoming very important in the development of glycobiology (3). At present, the term lectin is used in a broad sense to denote all types of carbohydrate-binding proteins that do not catalyze reactions with their ligands or that are antibodies (4).

The proteins present in algae which are capable of binding to and agglutinating cells were first identified by Boyd et al. (5) and designated as marine algal hemagglutinins. However, algal lectins were recently termed phycolectins $(6,7)$ and represent a group of proteins which preferentially bind glycoproteins and share some other characteristics such as relatively low molecular weights, no metal requirement for hemagglutination, and occurrence in monomeric forms.

Certain phycolectins have potent biological activities in vitro, including specific and nonspecific agglutination of erythrocytes (8), stimulation of mitogenic activity towards $\mathrm{T}$ lymphocytes from mouse spleen or human peripheral blood lymphocytes (9-11), inhibition of ADP or collagen-induced human platelet aggregation (6), and induction of neutrophil migration in vivo and in vitro (12). In addition, a lectin-gold conjugate has also been used as a new histochemical reagent (13).

An extract from the marine red alga Bryothamnion seaforthii (Turner) Kütz. agglutinates trypsin-treated erythrocytes from rabbits, chickens, and cows (14), and an extract from Bryothamnion triquetrum (S.G. Gmel.) M. Howe agglutinates enzyme-treated erythrocytes from rabbits, chickens, goats, pigs, and humans $(15,16)$. These investigators found that ammonium sulfate-precipitated fractions (F0/60) from both species contain lectins as one of their major constituents. There are two studies on the purification of lectins from the F0/60 of both species carried out with similar experimental protocols. Their general properties as shown by Calvete et al. (17) suggested that these protein molecules are not different from those described previously (16).

Although some substances produced by algae have antiviral, antifungal, antibacterial, hemolytic and toxic activities, little is known about the involvement of algal lectins in physiological functions. Preliminary studies have revealed that phycolectins from algae of the Brazilian northeastern coast present antinociceptive activities in several experimental models of nociception $(18,19)$.

However, other constituents from marine algae might also be responsible for some of their pharmacological activity. This is the case for sulfated polysaccharides which have been shown to present anticoagulant and antithrombotic properties $(20,21)$. Another study (22) has shown that polysaccharides from the red alga Porphyridium sp present hypocholesterolemic activity.

The aim of the present study was to further characterize the antinociceptive activity present in the crude fraction (F0/60) and in the lectin and carbohydrate fractions isolated from B. seaforthii and B. triquetrum in several experimental models of nociception in mice, in an attempt to elucidate the active constituents and their mechanism of action.

\section{Material and Methods}

\section{Plant material}

Alga specimens Bryothamnion seaforthii (Turner) Kütz. and Bryothamnion triquetrum (S.G. Gmel.) M. Howe were collected along the northeastern Brazilian coast (Flexeiras Beach, Trairi, CE, Brazil), brought to the laboratory in water-ice bags and kept at $-20^{\circ} \mathrm{C}$ until use. Algae were classified by Dr. A.C.M. Fortes-Xavier, Department of Biol- 
ogy, Federal University of Ceará, and exiccatae were deposited at the Prisco Bezerra Herbarium of the Federal University of Ceará (voucher No. 30.850).

\section{Drugs}

Bovine serum albumin, avidin, naloxone, cetylpyridinium chloride and papain were purchased from Sigma (St. Louis, MO, USA). Morphine sulfate was from Cristalia do Brasil S/A (Itapira, SP, Brazil), mannose was from Merck (Darmstadt, Germany) and cysteine was from Riedel-de-Haen (now Sigma-Aldrich, Munich, Germany). Formalin and acetic acid were purchased from Reagen and Vetec (Duque de Caxias, RJ, Brazil). All other drugs used were of analytical grade.

\section{Animals}

Male or female Swiss mice (25 g) from the Animal House of the Federal University of Ceará, maintained on a 12-h light/dark cycle with free access to water and food were used in all experiments. Experiments were carried out according to the "Guide for the Care and Use of Laboratory Animals" of the National Academy of Sciences, 1996, USA. The research project was approved by the University Hospital Ethics Committee of the Federal University of Ceará, Brazil.

\section{Preparation of F0/60 ammonium sulfate fractions and isolation of lectins}

For the preparation of $\mathrm{F} 0 / 60$ fractions and isolation of lectins from $B$. seaforthii and $B$. triquetrum, a previously described method (16) was used. The algae were thawed, rinsed with distilled water, ground to a fine powder under liquid nitrogen, stirred for $4 \mathrm{~h}$ with three volumes of $20 \mathrm{mM}$ sodium phosphate buffer, $\mathrm{pH} 7.0$, containing $0.15 \mathrm{M}$ $\mathrm{NaCl}$, filtered through nylon tissue and centrifuged at 7,000 $\mathrm{g}$ for $30 \mathrm{~min}$ at $4^{\circ} \mathrm{C}$.
The supernatant was acidified, left to stand for $16 \mathrm{~h}$ at $6-8^{\circ} \mathrm{C}$, centrifuged, and adjusted to $\mathrm{pH} 7.0$, followed by the addition of ammonium sulfate until $60 \%$ saturation. After $16 \mathrm{~h}$, the precipitated proteins were recovered by centrifugation (F0/60), resuspended in distilled water, dialyzed and applied to a DEAE-cellulose column. The column was equilibrated and eluted in one step with $20 \mathrm{mM}$ sodium phosphate buffer, $\mathrm{pH}$ 7.6, followed by elution with $1 \mathrm{M} \mathrm{NaCl}$ in the same buffer. Active fractions (PI-DEAE) from both species of algae did not adsorb to the column, and were pooled and rechromatographed on the same column. Lectin fractions were combined, dialyzed against water, and lyophilized (PI-DEAE). The procedure for the isolation of $B$. seaforthii and $B$. triquetrum lectins is a simple and reproducible one, and provides an average yield of $10-15 \mathrm{mg}$ protein $/ \mathrm{kg}$ of fresh algae. The preparations (PI-DEAE) were submitted to SDS-PAGE, presenting single bands. These lectins were shown to contain on average $7 \%$ (B. seaforthii) and $50 \%$ (B. triquetrum) carbohydrates (23). The solubility in water of the carbohydrate fraction of $B$. seaforthii was about $50 \%$ and that of $B$. triquetrum was more than $90 \%$. The crude protein fraction (F0/60) and lectins (PI-DEAE) were dissolved in distilled water before use.

\section{Preparation of the carbohydrate fractions}

Collected fresh algae were washed with distilled water and dried in an oven at $35^{\circ} \mathrm{C}$. Twenty grams of dried algae cut into small pieces were suspended in $1 \%$ sodium hypochlorite and washed with distilled water. The dried tissue was then suspended in 500 $\mathrm{ml}$ of $100 \mathrm{mM}$ sodium acetate buffer, $\mathrm{pH} 6.0$, containing $5 \mathrm{mM}$ cysteine, $5 \mathrm{mM}$ EDTA and $0.4 \%(\mathrm{w} / \mathrm{v})$ papain, and incubated at $60^{\circ} \mathrm{C}$ for $24 \mathrm{~h}$. The incubation mixture was filtered, and the supernatant saved. The residue was washed with distilled water and filtered, and the two filtrates were combined. 
Sulfated polysaccharides were precipitated with $17 \mathrm{ml} 10 \%$ cetylpyridinium chloride. After standing at room temperature for $48 \mathrm{~h}$, the mixture was centrifuged at $2,500 \mathrm{~g}$ for 20 $\min$ at $4^{\circ} \mathrm{C}$. The sulfated polysaccharides in the pellet were washed with $600 \mathrm{ml}$ of $0.05 \%$ cetylpyridinium chloride and centrifuged $(2,500 \mathrm{~g}, 20 \mathrm{~min})$. The remaining pellet was then dissolved with $150 \mathrm{ml} 2 \mathrm{M} \mathrm{NaCl}$ :ethanol $(100: 15, \mathrm{v} / \mathrm{v})$ and precipitated with $300 \mathrm{ml}$ absolute ethanol. After $24 \mathrm{~h}$ at $4^{\circ} \mathrm{C}$, the precipitate was collected by centrifugation $\left(2,500 \mathrm{~g}, 20 \mathrm{~min}\right.$ at $\left.4^{\circ} \mathrm{C}\right)$, washed with $300 \mathrm{ml}$ $80 \%$ (v/v) ethanol, followed by the same volume of absolute ethanol and finally by the same volume of acetone. The final precipitate was dried at room temperature. The yield was 21 and $12 \%$ for $B$. seaforthii and $B$. triquetrum, respectively. Carbohydrate fractions were dissolved in distilled water before use.

\section{Evaluation of antinociceptive activity}

The writhing, formalin, and hot-plate tests were applied to mice. In all cases, the crude protein fraction F0/60, lectins (PI-DEAE) or carbohydrate fractions were dissolved in distilled water, which was also used in an equivalent volume in controls.

Writhing test. Male and female Swiss mice were treated with fractions F0/60 (0.5 to $10 \mathrm{mg} / \mathrm{kg}$, ip, and 1 to $40 \mathrm{mg} / \mathrm{kg}$, po), lectins $(0.5$ to $5 \mathrm{mg} / \mathrm{kg}$, ip, and 0.5 to $10 \mathrm{mg} /$ $\mathrm{kg}, p o$ ), carbohydrate fractions ( 0.1 to $5 \mathrm{mg} /$ $\mathrm{kg}, i p$ ), $30 \mathrm{~min}$ (for intraperitoneal administration, ip) or 60 min (for oral administration, $p o$ ) before receiving a $0.6 \%$ acetic acid injection $(10 \mathrm{ml} / \mathrm{kg}$, ip), and the number of contractions was recorded after $5 \mathrm{~min}$ for 20 min (24). Controls received the same volume of distilled water. In another set of experiments, the writhing test was performed with lectins in the absence and presence of avidin $(1 \mathrm{mg} / \mathrm{kg}, i p)$ or D-mannose $(1 \mathrm{mg} / \mathrm{kg}$, $i p)$. In this case, avidin or mannose alone or previously mixed with the lectin was heated at $37^{\circ} \mathrm{C}$ for $1 \mathrm{~h}$ before administration. The test was then performed $30 \mathrm{~min}$ later as described above.

Formalin test. Twenty microliters of $1 \%$ formalin was injected into the right hind paw of male Swiss mice (25 g), and the licking time was recorded during the first $5 \mathrm{~min}$ (1st phase) and after $20 \mathrm{~min}$ (2nd phase) for 5 min each time. Animals were pretreated with $\mathrm{F} 0 / 60(0.5$ to $10 \mathrm{mg} / \mathrm{kg}$, ip, or 10 to $20 \mathrm{mg} / \mathrm{kg}$, po) or lectins ( 1 to $5 \mathrm{mg} / \mathrm{kg}$, ip, or 5 to $20 \mathrm{mg}$ / $\mathrm{kg}, p o$ ), 30 or $60 \mathrm{~min}$ for intraperitoneal or oral administration, respectively. Naloxone $(2 \mathrm{mg} / \mathrm{kg}, s c)$, an opioid antagonist, was injected $15 \mathrm{~min}$ before $\mathrm{F} 0 / 60$, lectins, or morphine $(5 \mathrm{mg} / \mathrm{kg}$, ip) used as standard $(25,26)$.

Hot-plate test. Male Swiss mice (25 g) were preselected according to their reactions to thermal stimuli (jumping or licking of hind limbs when placed on a hot plate at $55^{\circ} \mathrm{C}$ ). The cut-off point was set at $30 \mathrm{~s}$, and animals presenting a higher latency time were discarded (27). Latency times were recorded immediately before and 30,60 and $90 \mathrm{~min}$ after F0/60 (10 to $20 \mathrm{mg} / \mathrm{kg}$, ip) or lectin (5 to $10 \mathrm{mg} / \mathrm{kg}$, ip, or $10 \mathrm{mg} / \mathrm{kg}$, po) administration. To detect a possible involvement of the opioid system, animals were pretreated with naloxone $(2 \mathrm{mg} / \mathrm{kg}, s c) 15 \mathrm{~min}$ before injection of the fractions, lectins, or morphine (5 $\mathrm{mg} / \mathrm{kg}$, ip) used as standard.

\section{Statistical analysis}

Data were analyzed by ANOVA and by the Dunnett test as the post hoc test, and considered significant at $\mathrm{P}<0.05$.

\section{Results}

The results presented in Table 1 show that F0/60 (0.5 and $10 \mathrm{mg} / \mathrm{kg}$, ip , and 10 and $40 \mathrm{mg} / \mathrm{kg}, p o)$ and the lectin $(0.5$ and $1 \mathrm{mg} /$ $\mathrm{kg}$, ip and $p o$ ) from $B$. seaforthii were equally potent in causing inhibition of the acetic acid-induced abdominal contractions in mice. 
In both cases, the effect was greater after intraperitoneal (68 to $98 \%$ decreases) as compared to oral administration (44 to $74 \%$ decreases), and maximum inhibition was observed with the dose of $0.5 \mathrm{mg} / \mathrm{kg}$ of either F0/60 or lectin administered ip. A similar profile was observed after the administration of F0/60 and lectin from B. triquetrum. In this case, inhibition ranging from 65 to $88 \%$ was seen after ip administration of F0/60 or lectin ( 1 and $5 \mathrm{mg} / \mathrm{kg}$ ). After oral administration, $\mathrm{F} 0 / 60$ ( 1 and $5 \mathrm{mg} / \mathrm{kg}$ ) inhibited abdominal contractions by 64 and $78 \%$, respectively, while $B$. triquetrum lectin $(5$ and $10 \mathrm{mg} / \mathrm{kg}$ ) was somewhat less efficient (49 and 56\% inhibition, respectively).

In the formalin test (Figure 1A and B), ip administration of $\mathrm{F} 0 / 60(0.5$ and $1 \mathrm{mg} / \mathrm{kg})$ from $B$. seaforthii caused a significant inhibition of the 2nd phase of the response only with the high dose. No effect was detected on the 1st phase. However, F0/60 was effective on both phases, after the oral administration of 10 and $20 \mathrm{mg} / \mathrm{kg}$, producing inhibitions of 36 and 55\% (1st phase), and 58 and $88 \%$ (2nd phase), respectively. The results obtained with $B$. seaforthii lectin were similar to those obtained with F0/60. Thus, after ip administration of 1 and $5 \mathrm{mg} / \mathrm{kg}$, significant inhibitions were detected during the 2 nd phase (34 and $73 \%$, respectively). The oral administration was also effective although at higher doses (10 and $20 \mathrm{mg} / \mathrm{kg}$ ). A similar pharmacological profile was observed with $\mathrm{F} 0 / 60$ and the lectin from $B$. triquetrum.

The formalin test was also performed in the absence and presence of naloxone, an opioid antagonist. The effect of morphine and both lectins was totally reversed by naloxone in the 1st phase. Although the effect of morphine was also reversed in the 2 nd phase of the formalin test, $24 \%$ (B. seaforthii) and $30 \%$ (B. triquetrum) inhibition of the licking time remained after combination of the lectins with naloxone (Figure 2A and B).
The objective of the next experiment was to demonstrate the role of avidin and Dmannose in the antinociceptive effects of the lectins in the acetic acid-induced contractions in mice. While the antinociceptive activity of B. seaforthii lectin was unaltered after its administration with avidin, the effect was completely reversed after its administration with D-mannose. On the other hand, administration with avidin partially reversed the antinociceptive effect of $B$. triquetrum lectin alone. However, similarly to the lectin from $B$. seaforthii, the administration of the lectin from $B$. triquetrum with D-mannose also reversed its antinociceptive effect, and

Table 1. Effects of F0/60 and lectin fractions from Bryothamnion seaforthii (BS) and B. triquetrum (BT) on acetic acid-induced abdominal contractions in mice.

\begin{tabular}{|c|c|c|c|}
\hline \multirow[t]{2}{*}{ Group } & \multirow[t]{2}{*}{ No. of contractions/20 min } & \multicolumn{2}{|c|}{$\%$ Inhibition } \\
\hline & & Mean & Range \\
\hline Control (vehicle) & $42.8 \pm 1.56(32)$ & - & - \\
\hline \multicolumn{4}{|l|}{ BS F0/60 } \\
\hline 0.5 mg/kg, ip & $6.0 \pm 1.64(13)^{*}$ & 86 & $82.8-89.4$ \\
\hline $10.0 \mathrm{mg} / \mathrm{kg}$, ip & $0.7 \pm 0.34(10)^{*}$ & 98 & $97.7-99.1$ \\
\hline $10.0 \mathrm{mg} / \mathrm{kg}$, po & $23.9 \pm 2.39(9)^{*}$ & 44 & $40.8-47.8$ \\
\hline $40.0 \mathrm{mg} / \mathrm{kg}$, po & $11.3 \pm 1.64(6)^{*}$ & 74 & $70.9-76.5$ \\
\hline \multicolumn{4}{|l|}{ BS lectin } \\
\hline $0.5 \mathrm{mg} / \mathrm{kg}$, ip & $13.7 \pm 3.05(13)^{*}$ & 68 & $62.2-74.0$ \\
\hline $1.0 \mathrm{mg} / \mathrm{kg}$, ip & $9.8 \pm 1.98(7)^{*}$ & 77 & $73.4-81.1$ \\
\hline $0.5 \mathrm{mg} / \mathrm{kg}$, po & $15.8 \pm 2.17(18)^{*}$ & 63 & $59.5-67.0$ \\
\hline $1.0 \mathrm{mg} / \mathrm{kg}$, po & $20.0 \pm 1.60(11)^{*}$ & 53 & $51.3-55.3$ \\
\hline \multicolumn{4}{|l|}{ BT F0/60 } \\
\hline 1 mg/kg, ip & $11.1 \pm 2.77(12)^{*}$ & 74 & $68.7-79.8$ \\
\hline $5 \mathrm{mg} / \mathrm{kg}$, ip & $5.2 \pm 1.28(15)^{*}$ & 88 & $85.4-90.5$ \\
\hline $1 \mathrm{mg} / \mathrm{kg}$, po & $15.3 \pm 3.24(10)^{*}$ & 64 & $58.3-70.6$ \\
\hline $5 \mathrm{mg} / \mathrm{kg}$, po & $9.5 \pm 3.06(8)^{*}$ & 78 & $71.6-84.5$ \\
\hline \multicolumn{4}{|l|}{ BT lectin } \\
\hline 1 mg/kg, ip & $15.0 \pm 2.46(18)^{*}$ & 65 & $60.6-69.6$ \\
\hline $5 \mathrm{mg} / \mathrm{kg}$, ip & $9.3 \pm 1.97(23)^{*}$ & 78 & $74.5-82.3$ \\
\hline 5 mg/kg, po & $21.7 \pm 3.76(10)^{*}$ & 49 & $42.6-56.5$ \\
\hline 10 mg/kg, po & $19.0 \pm 3.49(6)^{*}$ & 56 & $49.3-62.4$ \\
\hline
\end{tabular}

Values are reported as means \pm SEM for the number of animals shown in parentheses. The data reported as range indicate the minimum and maximum values of the percentage of inhibition, indicating the dispersion of the mean of each group (No. of contractions/20 $\mathrm{min}$ ).

$* \mathrm{P}<0.05$ vs control (ANOVA and Dunnett as a post hoc test). 
the number of abdominal contractions was equal to that observed with D-mannose (Table 2).

Figure $3 \mathrm{~A}$ and $\mathrm{B}$ shows the effects of F0/60 and lectins in the hot-plate test. A significant increase (ranging from 29 to $78 \%$ ) in the latency to respond to thermal stimuli was seen 30 min after F0/60 administration $(20 \mathrm{mg} / \mathrm{kg}, i p)$, as compared to controls at the same time, and the effect lasted up to $90 \mathrm{~min}$.

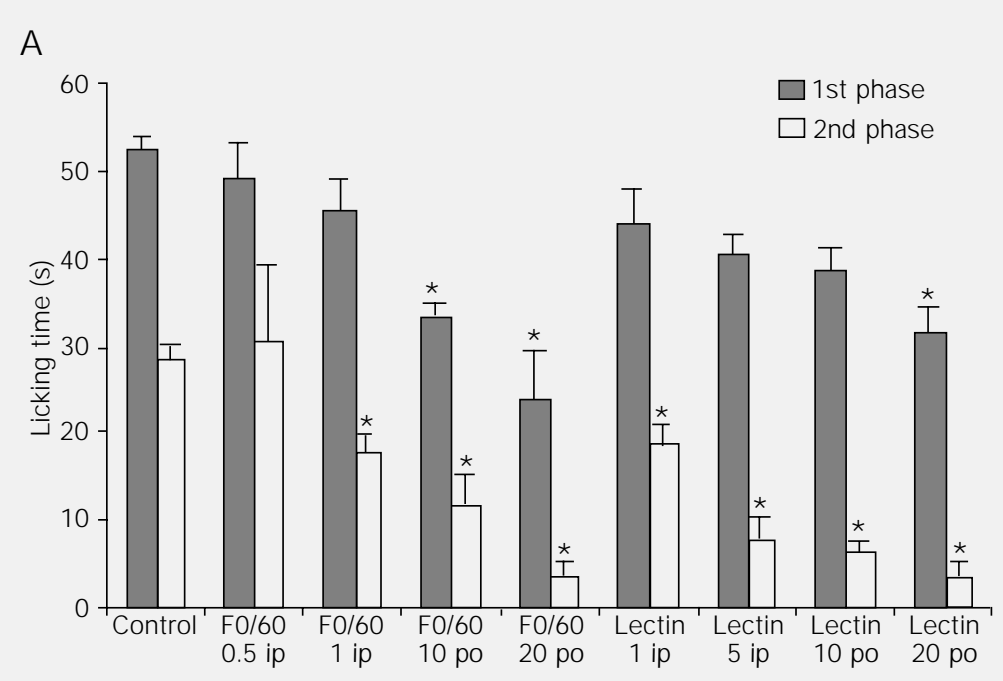

B

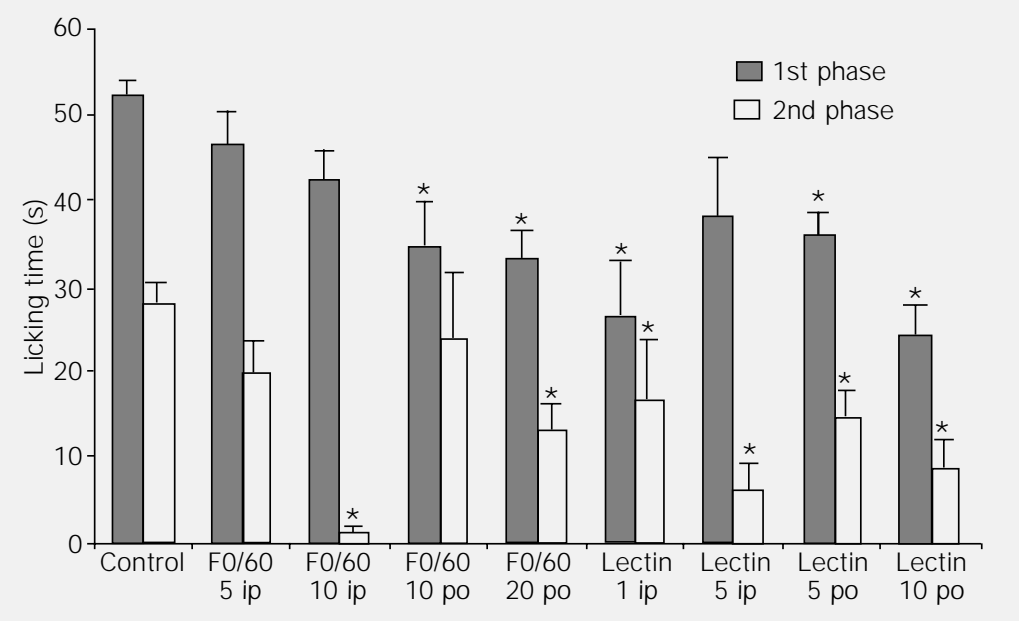

Figure 1. Effects of the crude F0/60 and lectin fractions from Bryothamnion seaforthii (A) and $B$. triquetrum $(B)$ on the formalin test in mice. Licking time $( \pm$ SEM) from 6 to 38 mice. Animals received fractions 30 (ip) or 60 (po) min before the intraplantar administration of $1 \%$ formalin, and measurements were done during the first 5 min (1st phase) and after 20 min (2nd phase) for $5 \mathrm{~min}$ each. Numbers under fractions indicate dose in $\mathrm{mg} / \mathrm{kg}$ and route of administration. $* \mathrm{P}<0.05$ vs control (ANOVA and Dunnett as a post hoc test).
A significant effect was also observed with B. seaforthii lectin after the administration of $10 \mathrm{mg} / \mathrm{kg}$, ip $(30,50$ and $58 \%$ increases at 30,60 and $90 \mathrm{~min}$, respectively) as compared to controls at the same times. Oral administration of $B$. seaforthii lectin $(10 \mathrm{mg} /$ $\mathrm{kg}, p o$ ) was also effective. Within the same dose range, $B$. triquetrum lectin presented similar effects. Morphine ( $5 \mathrm{mg} / \mathrm{kg}$, ip $)$, used as standard, increased latency time by 149 , 171 and 88\%, 30, 60 and 90 min after injection, respectively. Pretreatment with naloxone reversed the antinociception caused by F0/60 and lectin fractions.

Table 3 shows the effects of the carbohydrate fractions from $B$. seaforthii and $B$. triquetrum on the acetic acid-induced contractions. These fractions contain about $7 \%$ (B. seaforthii) and $50 \%$ (B. triquetrum) sulfated polysaccharides, as determined by the method of Dubois et al. (23), in addition to approximately $5 \%$ protein as contaminant. The yield based on algae dry weight was 21 and $12 \%$ for B. seaforthii and B. triquetrum, respectively. Interestingly, while the carbohydrates present in $B$. seaforthii were about $50 \%$ water soluble, those from B. triquetrum were $90 \%$ water soluble. In both cases, only water-soluble material was used, and the maximum effect (ranging from 63 to $72 \%$ inhibition) was observed with the dose of 5 $\mathrm{mg} / \mathrm{kg}$, ip.

\section{Discussion}

Although extracts from marine algae are known to possess several pharmacological properties, including anti-inflammatory activity (28), the present study showed for the first time, to our knowledge, the presence of antinociceptive activity in lectin and carbohydrate fractions from marine algae. Lectins are among the main constituents of algae and present a range of biological properties in vitro, including specific and nonspecific agglutination of erythrocytes and stimulation of lymphocyte transformation. Other reports 
Table 2. Effect of avidin and D-mannose on the antinociceptive effects of lectins from Bryothamnion seaforthii (BS) and B. triquetrum (BT) measured as acetic acid-induced abdominal contractions in mice.

\begin{tabular}{lcc}
\hline Group & $\begin{array}{c}\text { Route of } \\
\text { administration }\end{array}$ & No. of contractions \\
\hline Control & Vehicle & $32.8 \pm 1.08(25)$ \\
Avidin & ip & $24.1 \pm 2.60(25)$ \\
BS lectin & ip & $6.3 \pm 0.97 a(33)$ \\
& po & $20.0 \pm 1.60(11)$ \\
BT lectin & ip & $4.0 \pm 1.93 a(6)$ \\
& po & $17.6 \pm 1.96 a(5)$ \\
BS lectin & ip & $5.9 \pm 1.13 a, b(21)$ \\
+ avidin & po & $20.7 \pm 2.14(14)$ \\
BT lectin & ip & $16.0 \pm 1.37 a, b(5)$ \\
+ avidin & po & $17.4 \pm 4.82(5)$ \\
D-mannose & ip & $20.9 \pm 1.82(25)$ \\
BS lectin & ip & $29.0 \pm 3.94(10)$ \\
+ D-mannose & po & $27.7 \pm 1.63(9)$ \\
BT lectin & ip & $19.3 \pm 1.55(6)$ \\
+ D-mannose & po & $29.0 \pm 4.58(6)$ \\
\hline
\end{tabular}

Avidin and mannose alone or mixed with the lectin ( $1 \mathrm{mg} / \mathrm{kg}$ ) were previously incubated at $37^{\circ} \mathrm{C} 1 \mathrm{~h}$ before administration, and the test was performed as described in Methods. Values are reported as means \pm SEM for the number of animals in parentheses.

$a, b=P<0.05$ vs control and lectin, respectively (ANOVA and Dunnett as a post hoc test).
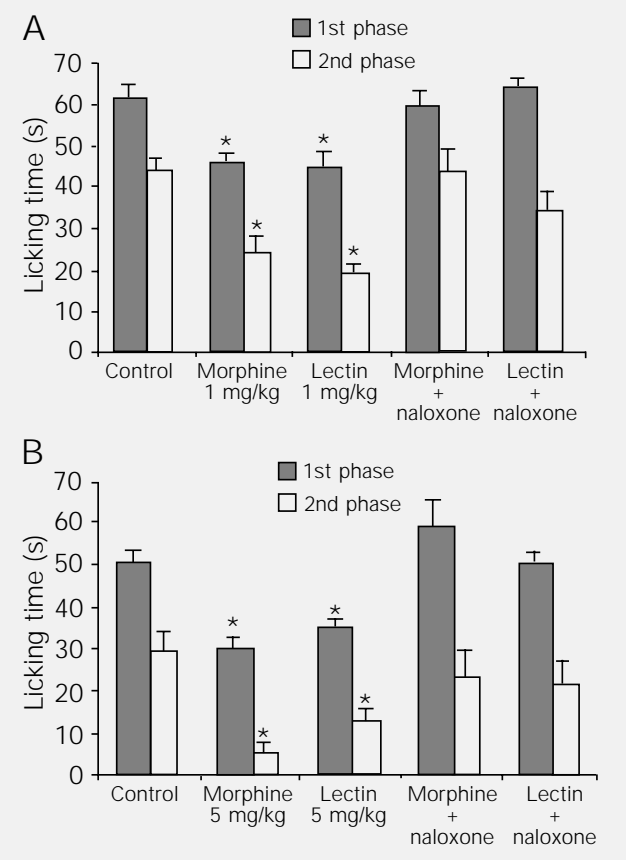

Figure 2. Role of the opioid system in the antinociceptive effects of lectins from Bryothamnion seaforthii (A) and B. triquetrum (B) in the formalin test in mice. Licking time (mean \pm SEM) recorded for 5 to 16 mice. Animals received lectin fractions ( 1 and $5 \mathrm{mg} / \mathrm{kg}$, ip) in the absence and presence of naloxone ( $2 \mathrm{mg} / \mathrm{kg}$, sc, injected $15 \mathrm{~min}$ before the lectin), 30 (ip) or 60 (po) min before the intraplantar administration of $1 \%$ formalin solution. Morphine ( $5 \mathrm{mg} / \mathrm{kg}$, ip) in the absence and presence of naloxone ( $2 \mathrm{mg} / \mathrm{kg}$, sc, injected 15 min before morphine) was used as standard. Measurements were made during the first 5 min (1st phase) and after 20 min (2nd phase) for 5 min each time. ${ }^{*} \mathrm{P}<0.05$ vs control (ANOVA and Dunnett as a post hoc test).
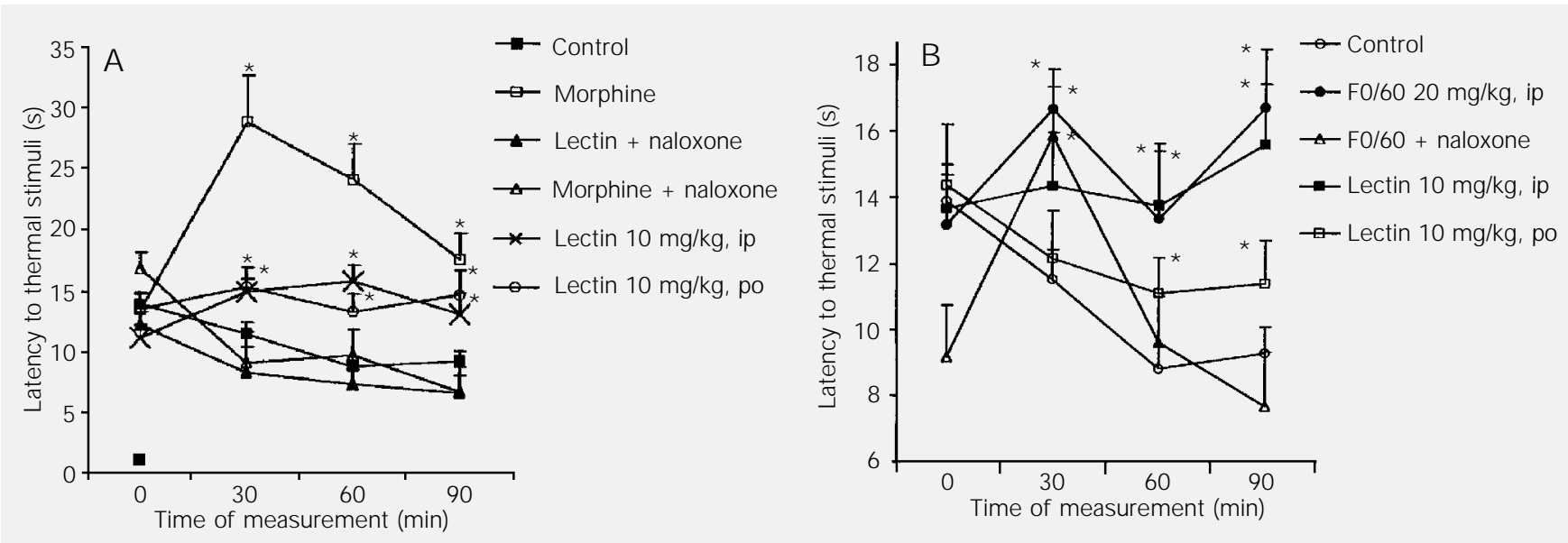

Figure 3. Possible involvement of the opioid system in the antinociceptive effects of F0/60 and lectin fractions from Bryothamnion seaforthii (A) and B. triquetrum (B) in the hot-plate test in mice. Latency to respond to thermal stimuli (mean \pm SEM) recorded for 8 to 10 mice. Latency times were recorded immediately before and 30,60, and 90 min after the administration of F0/60 or lectin fractions from B. seaforthii or B. triquetrum, in the absence or presence of naloxone (2 mg/kg, sc, injected $15 \mathrm{~min}$ before). Morphine (5 mg/kg, ip) in the absence or presence of naloxone (2 mg/kg, sc) was also used as standard. $* \mathrm{P}<0.05$ vs control at the same time point (ANOVA and Dunnett as a post hoc test). 
(29) have indicated that lectins possess neuromodulatory effects. They are also used as histochemical markers to study the distribution of glycoconjugates in mammalian tissues. Some years ago (13), a new histochemical reagent was developed utilizing colloidal gold coupled to a specific lectin from the green alga Codium fragile ssp tomentosoides. This lectin-gold conjugate binds to erythrocyte membranes from the human A1 blood group.

Besides hemagglutination activity, lectins from marine algae possess other actions such as the inhibition of human platelet aggregation (6). Lectins are proteins with sugarbinding subunits that recognize and bind to specific carbohydrates present on cell surfaces. The carbohydrate specificity of lectins has made them valuable for a variety of applications. Our study showed a potent antinociceptive activity present in crude fractions of B. seaforthii and B. triquetrum. Although more potent after ip administration, fractions were also active when administered orally.

Table 3. Effect of carbohydrate fractions from Bryothamnion seaforthii and B. triquetrum on the acetic acid-induced abdominal contractions in mice.

\begin{tabular}{lcrr}
\hline \multirow{2}{*}{ Group } & \multirow{2}{*}{$\begin{array}{c}\text { No. of contractions/ } \\
20 \mathrm{~min}\end{array}$} & \multicolumn{2}{c}{$\%$ Inhibition } \\
\cline { 3 - 4 } & & Mean & Range \\
\hline Control & $27.0 \pm 2.03(32)$ & - & - \\
B. seaforthii & & & \\
$0.1 \mathrm{mg} / \mathrm{kg}$, ip & $23.1 \pm 5.07(8)$ & 14.4 & $2.9-27.9$ \\
$1.0 \mathrm{mg} / \mathrm{kg}$, ip & $13.9 \pm 1.53(12)^{*}$ & 48.5 & $46.9-50.3$ \\
$5.0 \mathrm{mg} / \mathrm{kg}$, ip & $10.0 \pm 3.34(8)^{*}$ & 63.0 & $54.2-73.2$ \\
B. triquetrum & & & \\
$0.1 \mathrm{mg} / \mathrm{kg}$, ip & $23.4 \pm 3.90(7)$ & 13.3 & $4.6-21.9$ \\
$1.0 \mathrm{mg} / \mathrm{kg}$, ip & $9.5 \pm 2.60(8)^{*}$ & 64.8 & $58.3-72.4$ \\
$5.0 \mathrm{mg} / \mathrm{kg}$, ip & $7.7 \pm 1.32(7)^{*}$ & 71.5 & $69.0-74.4$ \\
\end{tabular}

Values are reported as means \pm SEM for the number of experiments in parentheses. The range shows the minimum and maximum values of the percent inhibition, indicating the dispersion of the mean of each group (No. of contractions/20 min). Carbohydrates were extracted as described in Methods. $* \mathrm{P}<0.05$ compared to control (one-way ANOVA and KruskalWallis as a post hoc test).
The amount of lectins present in crude fractions of algae was approximately $10 \%$. This means that the effect observed with 10 $\mathrm{mg} / \mathrm{kg}$ of the crude extract would correspond to that demonstrated with $1 \mathrm{mg} / \mathrm{kg}$ of isolated lectins. Surprisingly, the lectins from the two species were not equipotent on a weight basis. Naloxone at least partially reversed the antinociceptive effect of the lectins, indicating the involvement of the opioid system.

Another interesting point was the total blockade of the antinociceptive effect of $B$. seaforthii by D-mannose but not by avidin. This suggests that carbohydrate-binding domains are important for the biological effect of this lectin. In the case of the lectin from $B$. triquetrum, while pretreatment with avidin partially blocked its antinociceptive effect, a total blockade was also observed in the presence of D-mannose.

These results suggest that avidin interferes with the effect of the $B$. triquetrum lectin by interacting with the active sites of the lectin. It can be speculated that these lectins need larger and more complex molecules such as those of avidin in order to produce hemagglutination. It is known that D-mannose does not inhibit the hemagglutinating activity of either lectin. However, the bioavailability of D-mannose residues inside the avidin structure may be a requirement for the lectin-avidin interaction to occur.

Similar results have been reported in the literature for other lectins from marine algae (30). The blockade by avidin of the carbohydrate-binding sites of the B. triquetrum lectin suggests the involvement of other carbohydrate residues in the glycoprotein molecule besides D-mannose, which are equally important for the development of its antinociceptive activity. However, in both cases the most important role is played by $\mathrm{D}$ mannose, since this carbohydrate totally blocked the antinociceptive effects seen with lectins from both $B$. seaforthii and $B$. tri- 
quetrum.

Both lectins also presented a central effect as revealed by the hot-plate test in mice. Similarly to the results observed with the formalin test, these effects were also reversed by naloxone. As far as we know, this is the first report showing the presence of a central as well as a peripheral analgesic activity in both crude extracts and isolated lectins from two species of red marine algae. The effects were observed at low doses, a fact that makes these lectins potential candidates as analgesic drugs.

On the other hand, sulfated polysaccharides comprise a complex group of macromolecules with a wide range of biological properties such as anticoagulant and antithrombotic ones, which are present in several marine organisms including brown (31) and red algae (20). Recently, Farias et al. (32) characterized the structure of a sulfated p-galactan from the red alga Botryocladia occidentalis which presented a potent anticoagulant activity due to enhanced inhibition of thrombin and factor Xa by antithrombin and/or heparin cofactor II.

Recently, we showed (33) that the inactivation of lectins from the $\mathrm{F} 0 / 60$ fraction by its treatment with SDS plus B-mercaptoetha- nol did not interfere with the pharmacological effect present in this fraction, indicating that protein molecules are not responsible for the antinociceptive activity. Such data suggest that carbohydrates present in the lectins, and probably bound to them, are responsible for the antinociceptive effect of both $B$. triquetrum and B. seaforthii fractions. In addition, considering that the protein content of the carbohydrate fractions is very low (not higher than $10 \%$ ), it means that the dose of $5 \mathrm{mg} / \mathrm{kg}$ would correspond only to $500 \mu \mathrm{g}$ of protein at most, which is a low dose probably not contributing to the effect seen in the carbohydrate fraction. Preliminary spectroscopy experiments indicate that these carbohydrate components are sulfated polysaccharides.

We conclude that sulfated carbohydrates present in the lectin fractions from $B$. seaforthii and $B$. triquetrum are probably responsible for the antinociceptive effects of the algae.

\section{Acknowledgments}

The authors are grateful to Ms. M. Vilani Rodrigues Bastos for technical assistance.

\section{References}

1. Rogers DJ \& Fish BC (1991). Marine algae lectins. In: Kilpatrick DC, Van Driessche E \& Bog-Hansen TC (Editors), Lectin Reviews. Vol. 1. Sigma Chemical Company, St. Louis, MO, USA, 129-142.

2. Beuth J, Ko HL, Pulverer G, Uhlenbruck G \& Pichlmaier H (1995). Glycopinion minireview. Glycoconjugate J ournal, 12: 1-6.

3. Sharon N (1998). Lectins: from obscurity into the limelight. Protein Science, 7: 2042-2048.

4. Cummings RD (1997). Lectins as tools for glycoconjugate purification and characterization. In: Gabius HJ \& Gabius S (Editors), Glyco-sciences, Status and Perspective. Chapman Hall GmbH, Weinheim, Germany, 191-199.

5. Boyd WC, Almodovar LR \& Boyd G (1966).
Agglutinins in marine algae for human erythrocytes. Transfusion, 6: 82-83.

6. Matsubara K, Sumi H \& Hori K (1996). Platelet aggregation is inhibited by phycolectins. Experientia, 52: 540-543.

7. Rogers DJ , Blunden G \& Evans PR (1977). Ptilota plumosa, a new source of blood group B specific lectin. Medical Laboratory Sciences, 34: 193-200.

8. Hori K, Matsuda M, Miyasawa $K \&$ Ito $K$ (1987). A mitogen agglutinin from the red alga Carpopeltis flabellata. Phytochemistry, 26: 1335-1338.

9. Hori $K$, Ikegami $K$, Miyasawa $K \&$ Ito $K$ (1988). Mitogenic and antineoplastic isoagglutinins from the red alga Solieria robusta. Phytochemistry, 27: 2063-2067.

10. Okamoto R, Hori K, Miyazawa K \& Ito K
(1990). Isolation and characterization of a new hemagglutinin from the red alga Gracilaria bursa-pastoris. Experientia, 46: 975-977.

11. Lima HC, Costa FHF, Sampaio AH, Neves AS, Benevides NMB, Teixeira DIA, Rogers DJ \& Freitas ALP (1998). Induction and inhibition of human lymphocyte transformation by the lectin from the red marine alga Amansia multifida. J ournal of Applied Phycology, 10: 153-162.

12. Neves AS (1999). Lectina de Gracilaria caudata: isolamento, caracterização parcial e estudo comparativo do seu efeito indutor de migração de neutrófilos in vivo e in vitro, com o de outras lectinas de algas marinhas. Master's thesis, Universidade Federal do Ceará, Fortaleza, CE, Brazil. 
13. Griffin RL, Rogers DJ, Spencer-Phillips PTN \& Swain L (1995). Lectin from Codium fragile ssp. tomentosoides conjugated to colloidal gold: a new histochemical reagent. British J ournal of Biomedical Sciences, 52: 225-227.

14. Ainouz IL \& Sampaio AH (1991). Screening of Brazilian marine algae for hemagglutinins. Botanica Marina, 34: 211-214.

15. Ainouz IL, Sampaio AH, Benevides NMB, Freitas ALP, Costa FHF, Carvalho MC \& Pinheiro-J oventino $F$ (1992). Agglutination of enzyme treated erythrocytes by Brazilian marine algae. Botanica Marina, 35: 475-479.

16. Ainouz IL, Sampaio AH, Freitas ALP, Benevides NMB \& Mapurunga S (1995). Comparative study on hemagglutinins from the red algae Bryothamnion seaforthii and B. triquetrum. Revista Brasileira de Fisiologia Vegetal, 7: 15-19.

17. Calvete JJ, Costa FHF, Saker-Sampaio AH, Murciano MPM, Nagano CS, Cavada BS, Grangeiro TB, Ramos MV, Bloch J r C, Silveira SB, Freitas BT \& Sampaio AH (2000). The amino acid sequence of the agglutinin isolated from the red marine alga Bryothamnion triquetrum defines a novel lectin structure. Cellular and Molecular Life Sciences, 57: 343-350.

18. Vieira LAP, Andrade MCH, Bastos MVR, Freitas ALP \& Viana GSB (1999). Efeito analgésico periférico e central da lectina de Bryothamnion seaforthii Kütz. XIV Annual Meeting of the Federação de Sociedades de Biologia Experimental, Caxambu, MG, Brazil, August 25-28, 1999.

19. Andrade $\mathrm{MCH}$ (1999). Efeitos antinociceptivos e antiedematogênicos de lectinas das algas Bryothamnion seaforthii (Tumer) Kutz. e Bryothamnion triquetrum (S.G.
Gmel.) M. Howe. Master's thesis, Universidade Federal do Ceará, Fortaleza, CE, Brazil.

20. Carlucci MJ , Pujol CA, Ciancia M, Noseda MD, Matulewicz MC, Damonte EB \& Cerezo AS (1997). Antiherpetic and anticoagulant properties of carrageenans from the red seaweed Gigartina skottsbergii and their cyclized derivatives: correlation between structure and biological activity. International J ournal of Biological Macromolecules, 20: 97-105.

21. Duarte ME, Noseda DG, Noseda MD, Tulio S, Pujol CA \& Damonte EB (2001). Inhibitory effect of sulfated galactans from the marine alga Bostrychia montagnei on herpes simplex virus replication in vitro. Phytomedicine, 8: 53-58.

22. Dvir I, Chayoth R, Sod-M oriah U, Shany S, Nyska A, Stark AH, Madar Z \& Arad SM (2000). Soluble polysaccharides and biomass of red microalga Porphyridium sp alter intestinal morphology and reduce serum cholesterol in rats. British J oumal of Nutrition, 84: 469-476.

23. Dubois M, Gilles KA, Hamilton J K, Rebers PA \& Smith F (1956). Colorimetric method for the determination of sugars and related substances. Analytical Chemistry, 28: 350-356.

24. Koster $\mathrm{R}$, Anderson $\mathrm{M} \&$ \&e Beer EJ (1959). Acetic acid for analgesic screening. Federation Proceedings, 18: 412.

25. Fasmer OB, Berge OG \& Hole K (1985). Changes in nociception after lesions of descending serotoninergic pathways induced with 5,6-dihydroxytryptamine: different effects in the formalin and tail flick test. Neuropharmacology, 24: 729-734.

26. Tjolsen A, Berge O, Hunskaar S, Rosland J H \& Hole K (1992). The formalin test: an evaluation of the method. Pain, 51: 5-17.

27. Woolfe G\& MacDonald AD (1944). The evaluation of the analgesic action of pethidine hydrochloride (demerol). J oumal of Pharmacology and Experimental Therapeutics, 80: 300-307.

28. Payá M, Ferrandiz ML, Sanz MJ , Bustos G, Blasco R, Rios J L \& Alcaraz MJ (1993). Study of the antioedema activity of some seaweed and sponge extracts from the Mediterranean coast in mice. Phytotherapy Research, 7: 159-162.

29. Luizzi GM, Santacroce MP, Peumans WJ Van Damme EJ , Dubois B, Opdenakker G $\&$ Riccio P (1993). Regulation of gelatinases in microglia and astrocyte cell cultures by plant lectins. Glia, 27: 53-61.

30. Sampaio AH, Rogers DJ \& Barwell CJ (1998). A galactose-specific lectin from the red marine alga Ptilota filicina. Phytochemistry, 48: 765-769.

31. Mourão PA \& Pereira MS (1999). Searching for altematives to heparin: sulfated fucans from marine invertebrates. Trends in Cardiovascular Medicine, 9: 225-232.

32. Farias WRL, Valente AP, Pereira MS \& Mourão PAS (2000). Structure and anticoagulant activity of sulfated galactans. J ournal of Biological Chemistry, 22: 2929929307.

33. Viana GSB, Vieira LAPV, Lima MMLL, Andrade MCHA, Bastos MVR \& Freitas ALPF (2001). Determinação do provável constituinte químico ativo responsável pela atividade analgésica da alga marinha Bryothamnion seaforthii. XVI Annual Meeting of the Federação de Sociedades de Biologia Experimental, Caxambu, MG, Brazil, August 29 - September 1, 2001, 442. 